\title{
MODIFICAÇÃO DE ATO ADMINISTRATIVO INVÁLIDO NO LICENCIAMENTO DE CONSTRUÇÃO
}

\section{ARTIGO ORIGINAL}

OLIVEIRA, Ilka Suemi Nozawa de ${ }^{1}$

JÚNIOR, Nelson Saule ${ }^{2}$

OLIVEIRA, Ilka Suemi Nozawa de. JÚNIOR, Nelson Saule. Modificação de ato administrativo inválido no licenciamento de construção. Revista Científica Multidisciplinar Núcleo do Conhecimento. Ano 04, Ed. 12, Vol. 07, pp. 148-170. Dezembro de 2019. ISSN: 2448-0959, Link de acesso: https://www.nucleodoconhecimento.com.br/lei/licenciamento-de-construcao

\section{RESUMO}

A licença de construção constitui ato administrativo que tem por finalidade autorizar o interessado a construir em conformidade com as normas de direito público que disciplinam o direito de construir e a legislação urbanística. Na condição de ato administrativo, a licença de construção pode conter vício que estaria sujeita à invalidação, contudo, diante da possibilidade de modificação do ato administrativo, é possível que haja o aproveitamento total ou parcial dos efeitos gerados pelo ato inválido para o outro ato expedido em substituição ao anterior ou poderão ainda ser mantidos os efeitos que porventura ainda não tenham ocorrido pelo ato inválido. A possibilidade de modificação do ato administrativo tem como principal fundamento a segurança jurídica, estabilização das relações jurídicas, confiança legítima, boa-fé do administrado e da economicidade que, em determinados casos, o Direito aponta a

${ }^{1}$ Advogada, mestranda em Direito Urbanístico pela PUC/SP, cursou como aluna especial no mestrado em arquitetura e urbanismo na Universidade de Brasília - UnB as disciplinas Espaço e Organização Social e Espaço e Meio Ambiente (2016).

2 Doutorado em Direito. Mestrado em Direito. Especialização em Direito. 
possibilidade de sanar o vício para torná-lo regular. No âmbito do presente estudo são apresentadas as possibilidades de modificação do ato inválido por meio da estabilização, redução ou reforma, conversão e convalidação, admitindo serem estas as modalidades de modificação do ato administrativo inválido.

Palavras-chave: ato administrativo, invalidade, licença de construção, direito de construir, direito urbanístico.

\section{INTRODUÇÃO}

A licença de construção é um instrumento de controle urbanístico, que tem por objetivo atestar a observância das normas pelos seus destinatários, sendo a competência do Poder Público realizar o controle. Na ordenação da ocupação do solo, o licenciamento de construção tem como finalidade atestar a conformidade das normas de direito público que disciplinam o direito de construir e as restrições urbanísticas, sem prejuízo da incidência das normas de direito privado, denominados direito de vizinhança, à luz do que prescreve o art. 1.299 do Código Civil (SILVA, 2015).

Para que seja possível alcançar a expedição da licença de construção devem ser atendidos os requisitos legais exigidos pela legislação urbanística que, se devidamente cumpridos, a Administração Pública tem o dever de reconhecer o direito do interessado e expedir o Alvará de Construção, por representar um direito do administrado já preexistente.

A licença de construção, na condição de ato administrativo, se verificado algum vício, pode ser inválida e mesmo assim ser eficaz. Nesta condição, a licença de construção inválida pode sujeitar-se à modificação, seja por meio do aproveitamento total ou parcial dos efeitos gerados pelo ato inválido para o outro ato expedido em substituição ao anterior ou poderão ser mantidos os efeitos que porventura ainda não tenham ocorrido pelo ato inválido, sendo este o objeto central do presente estudo.

Cabe destacar que o direito urbanístico constitui um importante ramo do direito que merece ser aprofundado diante de uma realidade que envolve ordenar o interesse da 
coletividade no meio urbano, especialmente no âmbito do direito administrativo, sujeito a controle pela Administração Pública.

No Brasil, o processo de ocupação do solo foi fortemente influenciado por núcleos de aglomerações que tinham atividades relacionadas ao período colonial, como produção de café, extração de minério, cana-de-açúcar, dentre outras atividades. Inicialmente a ocupação se desenvolveu ao longo da costa litorânea, posteriormente em Minas Gerais, Goiás e Brasília com a criação da Capital e a forte concentração pelo processo de industrialização fixada no triângulo São Paulo, Rio de Janeiro e Minas Gerais (SILVA, 2015).

A ocupação e uso do solo no Brasil foi marcada especialmente pelas atividades desenvolvidas no período colonial, sendo que a concentração da população nas cidades foi influenciada pelas atividades econômicas desenvolvidas ao longo do tempo. Esse fenômeno gerou a necessidade de intervenção do Poder Público para pacificar conflitos e organizar o processo de ocupação do solo no meio urbano.

Por meio da intervenção do Poder Púbico na propriedade privada e na vida econômica e social das aglomerações urbanas e no meio rural é que se concretizam os objetivos de humanização, ordenação e harmonização dos ambientes em que vive o Homem, pois tais atividades que visam a realização do interesse da coletividade não seria, possíveis senão pela atividade do Poder Público. Assim, o direito urbanístico, no aspecto científico, é o ramo do direito público que tem por objeto expor, interpretar e sistematizar as normas e princípios reguladores da atividade urbanística (SILVA, 2015).

As normas de direito urbanístico objetivam assegurar os interesses da comunidade, disciplinam o uso, a ocupação e o parcelamento do solo urbano, além de disciplinar o sistema viário e, de forma mais ampla, regular o planejamento urbano impondo limitações para o exercício do direito de propriedade e de construir, além de instituir instrumentos de intervenção urbana (SAULE, 1997). 
No Brasil, a política de desenvolvimento urbano norteia-se por princípios constitucionais, especialmente pelo disposto nos artigos 182 e 183 da Constituição Federal, sendo competência do legislador federal editar normas gerais em matéria de direito urbanístico, assim como compete aos Estados e Municípios editar normas específicas, com fundamento na competência privativa em matéria de direito urbanístico, assegurada pela Constituição Federal (MARTINS, 2015)[3].

$\mathrm{O}$ art. 30, inciso VIII, da Constituição Federal estabelece a competência do Município para "promover, no que couber, adequado ordenamento territorial, mediante planejamento e controle do uso, do parcelamento e da ocupação do solo urbano", assim como o art. 24, I, da Constituição Federal, fixa a competência da União para editar normas gerais de direito urbanístico.

Além da previsão constitucional, a lei n 10.257/2001 denominada Estatuto da Cidade, introduziu diretrizes básicas que objetivam a ordenação do pleno desenvolvimento das funções sociais da cidade e da propriedade urbana, em especial, definiu que no âmbito Municipal e do Distrito Federal, o Plano Diretor é o instrumento básico para o desenvolvimento e expansão urbana, como forma de cumprir o objetivo de ordenar o pleno desenvolvimento das funções sociais da cidade e da propriedade urbana.

O planejamento municipal e distrital, no âmbito do direito urbanístico, deverá ser concretizado por meio do Plano Diretor, assim como por meio de norma que discipline o parcelamento, o uso e ocupação do solo, conforme estabelecido no artigo $4^{\circ}$ do Estatuto da Cidade, sendo competência dos Municípios e do Distrito Federal, o estabelecimento de normas edilícias, seguindo ao que dispõe o artigo $2^{\circ}$, incisos $\mathrm{VI}$ e XV do citado Estatuto da Cidade, em cumprimento à função social da propriedade urbana.

O direito de construir, previsto no art. 1.299 do Código Civil, garante ao proprietário o exercício desse direito, devendo ser observados o direito de vizinhança e as normas urbanísticas que impõe certas restrições, como por exemplo, restrições de uso, altura máxima, coeficiente de aproveitamento, recuos, taxa de permeabilidade, taxa de 
ocupação, necessidade de pagamento de contrapartidas urbanas, seja por meio de outorga onerosa do direito de construir ou de alteração de uso do solo, entre outras.

O administrado para exercer o direito de construir deverá submeter pedido previamente à Administração Pública a fim de obter a licença de construção, conforme exigido pela legislação urbanística local. O pedido tramitará em procedimento administrativo e, desde que atendidos os requisitos, a Administração Pública expedirá a licença por meio do denominado Alvará de Construção.

Há, no entanto, situações em que atos administrativos são praticados no procedimento administrativo ou até mesmo $\mathrm{o}$ ato final conclusivo em desconformidade com o Direito globalmente considerado, cujo vício pode acarretar a invalidação do ato administrativo. Nesta hipótese, em consideração aos princípios da segurança jurídica, estabilização das relações jurídicas, confiança legítima, boa-fé do administrado e da economicidade, o Direito aponta a possibilidade de sanar o vício para torná-lo regular.

O presente estudo visa abordar as formas de modificação do ato administrativo inválido da licença de construção em que há o dever de a Administração corrigir o vício.

Dessa forma, nos tópicos a seguir serão abordados os aspectos jurídicos relativos aos temas: (i) da licença de construção - ato administrativo de competência vinculada; (ii) da licença de construção inválida; (iii) das formas de modificação do ato administrativo inválido, nas modalidades da estabilização, redução ou reforma, conversão e convalidação; (iv) escolha do meio de correção; e, (v) conclusão.

\section{DA LICENÇA DE CONSTRUÇÃO - ATO ADMINISTRATIVO DE COMPETÊNCIA VINCULADA}

As normas urbanísticas visam disciplinar a ordenação do território e para essa afirmação, José Afonso da Silva, ensina que o direito urbanístico é um ramo do direito que congrega "um conjunto de normas jurídicas reguladoras da atividade do Poder 
Público destinada a ordenar os espaços habitáveis - o que equivale dizer: conjunto de normas jurídicas reguladoras da atividade urbanística" (SILVA, 2012, p. 37).

A Constituição Federal de 1988 atribuiu competência concorrente à União, aos Estados e ao Distrito Federal para legislar sobre matéria de direito urbanístico, restringindo à União, no âmbito da legislação concorrente, editar normas gerais e aos Estados e ao Distrito Federal editar normas específicas nos termos do $\S^{\circ}{ }^{\circ}$ do art. 24.

Na hipótese de a União editar normas gerais, o §2ำ do art. 24 da Constituição Federal estabelece que os Estados e o Distrito Federal devem legislar por competência suplementar. Além disso, compete aos Municípios e ao Distrito Federal legislar sobre assuntos de interesse local, nos termos do art. 30, I da Constituição Federal, assim como editar o Plano Diretor, nos termos do art. 182, $\S^{1^{\circ}}$ da Constituição Federal.

Ao regulamentar os arts. 182 e 183 da Constituição Federal de 1988, o Estatuto da Cidade (Lei ํㅜ 10.257/2001) instituiu no art. 2ํ diretrizes básicas que objetivam ordenar o pleno desenvolvimento das funções sociais da cidade e da propriedade urbana, sendo de competência municipal e do Distrito Federal, como acima citado, legislar sobre assuntos de interesse local. Saule (1997) ensina que

O direito de propriedade é garantido desde que atenda a sua função social, de acordo com o artigo $5^{\circ}$ incisos XXII e XXIII. A propriedade privada como um dos princípios gerais da ordem econômica, para atender a sua função social deve estar vinculada as finalidades de ordem econômica de assegurar a todos a existência digna, conforme os ditames da justiça social. A função social da propriedade em consonância com os demais princípios constitucionais, é o mandamento principal do regime da propriedade urbana que deve ser disciplinado pelo direito público (SAULE, 1997, p. 54 e 55).

As normas que tratam de planejamento e controle do uso, do parcelamento e da ocupação do solo urbanos são consideradas de interesse local e, portanto, de competência privativa dos Municípios e do Distrito Federal com base no inciso VIII do art. 30 da Constituição Federal. Conforme as regras de competência estabelecidas pela Constituição Federal, cabe aos Municípios estabelecer normas a fim de disciplinar o zoneamento do solo, que compreende tanto a finalidade da edificação 
quanto ao gabarito e o direito de construir, que inclui ainda o estabelecimento de condições de higiene, salubridade, segurança e estética urbana (DALLARI, 2014).

No plano constitucional, dentre os direitos e garantias fundamentais, no capítulo I que trata dos direitos e deveres individuais e coletivos, consta o direito de propriedade assim como a determinação que a propriedade deverá atender a sua função social (art. 5ㅇ, XXII e XXIII).

O direito de propriedade deve relacionar-se com outros princípios e regras constitucionais e infraconstitucionais, especialmente em relação ao planejamento e ordenamento territorial. Por esta razão, o direito de construir é assim, condicionado às prescrições administrativas (MALUF, 2007).

O direito de construir está previsto no art. 1.299 do Código Civil, que garante ao proprietário, o direito de construir, devendo observar, entretanto, o direito dos vizinhos e os regulamentos administrativos. Segundo Figueiredo (2005):

Assim conceituada, verificamos ser a licença para construir um ato administrativo constitutivo-formal, possibilitando àquele em favor de quem é expedida, o direito de levar a cabo a construção, nos termos em que foi deferida: isto é, de acordo com o projeto aprovado e no prazo estipulado (FIGUEIREDO, 2005, p. 128).

As licenças urbanísticas, especialmente as de construção, apresentam-se como ato administrativo vinculado, classificado também como ato urbanístico isolado[4], em que o interessado é obrigado a requerê-las e, se preenchidos os requisitos legais, não podem ser negadas pela Administração Pública. As modalidades mais comuns são as licenças para edificar, reformar, reconstruir ou demolir, além das licenças para atividades comerciais, industriais, institucionais ou de prestação de serviços. A licença para edificar "não constitui nem uma autorização, nem uma concessão, mas um ato de controle de um direito predeterminado quanto ao seu conteúdo" (SILVA, 2012, p. 437-439). 
A diferença entre licença e autorização é que a primeira consiste em ato vinculado e a segunda é classificada como ato de competência discricionária, sendo a precariedade uma de suas características (FIGUEIREDO, 2005).

A licença de construção, portanto, não tem a natureza de constituir direitos, mas tão somente declarar direitos subjetivos preexistentes, sendo que a autorização, em contrapartida, pressupõe a criação de um novo direito, que outorga efeitos constitutivos (BATISTA DOS SANTOS, 2001).

O procedimento administrativo para o licenciamento de construção deve seguir, portanto, as diretrizes fixadas por normas municipais que, e, se atendidos os requisitos, a Administração Pública expede o Alvará de Execução ou Alvará de Construção após a aprovação do projeto de arquitetura. Ao término da construção, cumpridas as exigências edilícias e urbanísticas, a Administração Pública atesta o seu cumprimento por meio do auto de conclusão ou do habite-se (SILVA, 2012).

No procedimento administrativo até se alcançar o momento da expedição da licença para construir, diversos atos administrativos em série ordenada são praticados, sendo que cada um deles mantém a sua autonomia e são conectados para produção do ato final. Nas lições de Martins (2019):

No procedimento administrativo: (a) cada um dos atos conserva a sua autonomia, de modo que há uma série ordenada de atos administrativos autônomos; (b) todos os atos se conectam numa unidade de efeito jurídico, todos estão vinculados causalmente, de modo que cada um supõe o anterior e o último supõe o grupo inteiro (MARTINS, 2019, p. 135).

A autoridade municipal a quem compete apreciar o pedido de licença para construir não tem competência discricionária, o que significa que não pode deferir ou indeferir o pedido fundamentado por razões de conveniência e oportunidade (DALLARI, 2014).

A licença de construção, portanto, constitui ato administrativo de competência vinculada em que a Administração Pública, se atendidos os requisitos legais, confere ao particular a possibilidade de exercer plenamente o direito de construir. Trata-se, 
portanto, de ato de conteúdo declaratório em que a Administração reconhece um direito prévio desde que respeitadas às regras vigentes[5].

É possível, contudo, que licenças de construção sejam concedidas pela Administração Pública com vícios sujeitos à invalidação, sejam nos atos praticados no procedimento administrativo até se alcançar o ato conclusivo ou mesmo no Alvará de Construção, que representa $O$ ato conclusivo da licença de construção. $O$ presente estudo visa abordar as formas de modificação do ato administrativo inválido da licença de construção em que há o dever de a Administração corrigir o vício.

\section{DA LICENÇA DE CONSTRUÇÃO INVÁLIDA}

No âmbito do presente estudo, adota-se a posição teórica de que ato administrativo válido é aquele que não possui vício que imponha à Administração o dever de corrigilo. De outro lado, atos administrativos inválidos são aqueles considerados com vício em que há o dever de a Administração repará-lo. Nas lições de Martins (2019),

$O$ ato administrativo inválido é aquele cujo defeito gera para a Administração o dever de repará-lo (pela invalidação, vale dizer, pela extinção - infra, Cap. V - 3.2.4 -, ou pela convalidação, pela conversão, pela redução, vale dizer, pela modificação - infra, Cap. VI - 3). Se o ato administrativo possui um vício que exige da Administração a prática de outro ato administrativo (de invalidação, de convalidação etc.) para corrigi-lo, há invalidade (MARTINS, 2019, p. 163).

Para compreensão da teoria adotada acerca da validade do ato administrativo, se considerar como aqueles praticados em conformidade com o Direito e, portanto, de acordo com os princípios e regras constitucionais e as demais leis vigentes, estariam excluídos dessa classificação aqueles atos administrativos que são válidos, mas contrários ao direito, como no caso dos atos irregulares (MARTINS, 2019)[6].

A classificação dos atos inválidos é bastante controvertida na doutrina, sendo que a grande maioria adota a classificação de que os atos inválidos dividem-se em atos nulos ou anuláveis. Essa classificação foi adotada com base da interpretação da teoria das nulidades desenvolvida no Direito Civil e diante da ausência de uma regra 
específica para o Direito Administrativo, boa parte da doutrina, como afirmado, ainda adota a classificação, embora de forma equivocada (BANDEIRA DE MELLO, 2019)[7].

Para o desenvolvimento do presente trabalho, considera-se que a tradicional classificação dos atos administrativos inválidos em atos jurídicos nulos e anuláveis são próprias do direito privado e não são adequadas para o Direito Administrativo, sob pena de equívocos e distorções em sua aplicação, apoiando-se nas justificativas apresentadas por Martins (2019), no seguinte sentido:

Esses diferentes critérios, porém, não permitem a classificação dos atos inválidos; devem ser examinados individualmente: tudo dependerá da análise das circunstâncias fáticas e jurídicas, ou seja, da ponderação efetuada pelo agente público quando da apreciação da invalidade. Conclui-se: é insatisfatória a classificação dos atos administrativos inválidos em nulos e anuláveis; não há uma classificação satisfatória para eles, todas as classes possíveis dependem de um critério definidor cuja configuração, em não raras vezes, exige a análise do caso concreto (MARTINS, 2019, p. 171).

Por outro lado, quanto ao ato administrativo inválido de licença de construção, cabe analisar as formas de modificação desse ato inválido, partindo-se da compreensão de que o Direito globalmente considerado aponta em benefício para torná-lo regular e, diante dessa premissa, é possível afirmar que nem sempre um ato considerado inválido deverá ser extinto por meio da invalidação.

Para tornar $\mathrm{o}$ ato administrativo regular, poderá haver o aproveitamento total ou parcial dos efeitos gerados pelo ato inválido para o outro ato expedido em substituição ao anterior ou, ainda, a manutenção dos efeitos que podem ainda não ter sido gerados pelo ato inválido. Importante considerar, ainda, que o vício pode ocorrer no ato administrativo praticado no procedimento administrativo que deu origem à licença de construção, na medida em que o procedimento administrativo, como mencionado, é constituído por diversos atos administrativos em série ordenada e todos eles, embora autônomos, estão conectados para a produção do ato final (MARTINS, 2019).

A exemplo da afirmação apresentada, é possível que a legislação municipal imponha ao administrado o pagamento de outorga onerosa do direito de construir ou outorga 
onerosa de alteração de uso, que constituem instrumento de política urbana obrigatório em determinadas hipóteses, como condição prévia à expedição da licença de construção. Suponhamos que o pagamento não tenha sido realizado em razão de ato administrativo praticado no procedimento administrativo que tenha erroneamente afastado a incidência da hipótese de cobrança e a licença de construção tenha sido expedida pela Administração Pública. Neste caso apresentado, por se tratar de vício procedimental, entende-se que, o vício pode ser sanado mediante convalidação, impondo ao administrado o pagamento da contrapartida urbana, restaurando-se a legalidade.

Em continuação à análise do caso apresentado, pressupondo que o administrado tem o direito à obtenção da licença de construção, tendo atendido todas as exigências impostas no procedimento administrativo e por equívoco da Administração foi realizado cálculo a menor da contrapartida urbana, considerando tratar-se de ato administrativo vinculado, na ponderação dos princípios incidentes, não havendo máfé, entende-se possível a convalidação do ato administrativo e não a anulação com imposição de indenização, porque nesta hipótese não se trata de licença de construção expedida com fundamento em direito que sequer existia, pelo contrário, se trata de um direito preexistente em que houve a confiança do administrado na declaração feita pela Administração Pública.

Diante de situações jurídicas como as acima apresentadas, cabe discorrer sobre as possiblidades de modificação do ato inválido por meio da estabilização, redução ou reforma, conversão e convalidação, admitindo serem estas as modalidades de modificação do ato administrativo inválido, diferentemente da posição apresentada por alguns doutrinadores[8]. 


\section{DAS FORMAS DE MODIFICAÇÃO DO ATO ADMINISTRATIVO INVÁLIDO}

\subsection{ESTABILIZAÇÃO}

A estabilização é considerada uma modalidade de modificação do ato administrativo inválido, mas que a correção está vinculada a fato jurídico, uma vez que "o decurso de certo lapso de tempo aliado a outros fundamentos elencados no sistema jurídico outorgam validade à nova situação que se estabelece, gerando a situação de pode ser denominada como estabilização". A estabilização difere da convalidação, na medida em que na estabilização $o$ ato, total ou parcialmente, permanece ao longo do tempo da forma como foi editado, ostentando o vício original. Em contrapartida, a convalidação se concretiza mediante a edição de novo ato corrigindo-se $o$ ato original com a supressão do vício que maculou o ato, no sistema jurídico outorgando-lhe validade (BIGOLIN, 2007, p. 103).

Nas lições de Reale (1968), em excepcionalíssimas hipóteses é possível a estabilização dos atos sanáveis não só em razão do tempo decorrido, mas diante das circunstâncias que afastam a existência de dolo ou quando se verificam presentes valores éticos ou econômicos positivos a favor da permanência do ato irregular (REALE, 1968).

Nesse sentido, segundo Martins (2019),

Quanto mais relações jurídicas o ato administrativo inválido instituir - ou seja, quanto mais efeitos gerar -, maior será o peso da estabilização das relações jurídicas (aspecto subjetivo da segurança jurídica, conforme supra, Cap. V-3.2.4.2), e, portanto, maiores serão as razões em prol de sua manutenção no sistema. Em muitas situações, o peso dos princípios que justificam a conservação do ato inválido é tão acentuado que dispensa até a formal edição de uma norma jurídica para o saneamento do vício; ele não se dá por força de uma atuação do Estado, é espontâneo (MARTINS, 2019, p. 402).

Esta é a única hipótese em que o ato inválido propriamente não é retirado do sistema jurídico, pois o simples fato jurídico no decurso do tempo, permite, por meio do 
reconhecimento da Administração ou do Judiciário que reconheça a estabilização. Deve-se atentar, contudo, que não é qualquer fato jurídico capaz de permitir a estabilização, mas são aqueles que estão em conformidade com os princípios informadores do direito administrativo, em especial o princípio da boa-fé e da segurança jurídica (BIGOLIN, 2007).

Destaca-se neste ponto, os atos de efeitos favoráveis ao administrado e atos de efeitos desfavoráveis ao administrado, classificados por alguns doutrinadores como atos ampliativos de direito e atos restritivos de direitos[9], tendo em vista que a depender do ato administrativo, haverá limites à invalidação, que Weida Zancaner apresenta como "barreiras ao dever de invalidar". Conforme posicionamento apresentado pela mesma autora, considerando que os atos inválidos geram consequências jurídicas, há situações, em especial dos atos ampliativos de direitos, que são merecedoras de proteção, principalmente porque os efeitos gerados em decorrência do ato inválido pode apresentar vedação à Administração para invalidação, pois esbarraria no princípio da segurança jurídica e da boa-fé (ZANCANER, 2008, p. 73-75).

Considerando, portanto, os princípios da segurança jurídica e da boa-fé, decorrido prazo razoável, haverá o dever de reconhecimento da estabilização do ato administrativo, protegendo-se especialmente os efeitos gerados pelo ato viciado.

$\mathrm{Na}$ estabilização, considerando-se, portanto, que o ato administrativo permanecerá da forma como foi editado, ostentando o vício original, não haverá a edição de uma nova norma jurídica, como ocorre, por exemplo, no caso da convalidação. Nesta hipótese, o ato inválido torna-se um ato irregular (MARTINS, 2015).

A ponderação a ser realizada entre todos os princípios envolvidos deve levar em consideração a boa-fé dos envolvidos, assim como os efeitos gerados e a máxima realização do interesse público (BIGOLIN, 2007)[10]. 
Assim, na ponderação, a prescrição ou princípios gerais do Direito, como o princípio da segurança jurídica e boa-fé é que justificam a permanência do ato viciado no sistema como se fossem válidos (CÂMARA, 2002).

A Administração Pública, em observância ao ordenamento jurídico que não tolera a eternização dos conflitos, deve ter as suas ações sujeitas também a prazos, quer para tutelar seus direitos perante Poder Judiciário, quer para desfazer seus próprios atos (SAMPAIO SILVA, 2001)[11].

Visando, portanto, a proteção do ato administrativo admite-se a estabilização dos atos viciados que tenham ampliado a esfera jurídica de direitos, uma vez ultrapassados o prazo de 5 anos contados de sua produção (SIMÕES, 2004).

Apesar de o decurso do tempo ser um fator importante, não pode ser analisado isoladamente, pois é imprescindível a constatação da boa-fé do administrado[12].

Analisando-se a licença de construção expedida com vício, por exemplo, tendo sido aprovada com 100m2 (cem metros quadrados) de área computável a mais do que seria permitido pela legislação urbanística municipal de empreendimento de aproximadamente $15.000 \mathrm{~m} 2$ (quinze mil metros quadrados) de área total construída, decorridos 8 anos do Alvará de Construção e 6 anos da Carta de Habite-se, desde que atestada a boa-fé do administrado, prima facie, entende-se possível admitir a estabilização do ato administrativo, em observância aos princípios incidentes, especialmente da segurança jurídica e da boa-fé do administrado.

\subsection{REDUÇÃO OU REFORMA}

A redução ou reforma são denominações apresentadas por diferentes doutrinadores, mas que contém o mesmo significado[13]. Consiste em espécie de modificação de ato administrativo que tem por objetivo a exclusão da parte inválida do ato viciado, mantendo-se a parte válida (MARTINS, 2019). 
Nesta modalidade de modificação do ato administrativo inválido, portanto, haverá supressão somente da parte viciada, em que será mantida a eficácia da parte não contaminada pela ilegalidade (NETTO DE ARAÚJO, 1999).

Os efeitos serão retroativos, na medida em que 0 ato redutor retira 0 ato inválido do sistema e toma para si parte dos efeitos produzidos por ele (MARTINS, 2019)[14].

Imagine-se, por exemplo, licença de construção expedida em que foi identificado no Alvará de Construção o licenciamento de construção para uso comercial e institucional, quando a legislação urbanística local permitia tão somente o uso institucional. Neste exemplo, prima facie, entende-se possível a redução da licença de construção para admitir tão somente o uso permitido institucional.

\subsection{CONVERSÃO}

A conversão constitui forma de modificação do ato inválido que tem por efeito principal a transformação de um ato inválido em outro válido de conteúdo diferente do anterior, podendo ocorrer em atos administrativos de competência vinculada ou discricionária. Da mesma forma que ocorre na redução ou reforma, o ato convertedor retira 0 ato inválido do sistema e toma para si os efeitos que foram produzidos por ele (MARTINS, 2019).

Na conversão, o ato inválido é substituído por outro ato, conferindo os mesmos efeitos que do ato inválido. Segundo os esclarecimentos de Edmir Netto de Araújo,

Com este instrumento, portanto, a Administração não convalida os elementos inválidos de um ato, mas, na verdade, substitui um ato que, com tais elementos é ilegal, por outro, conferindo outra base aos efeitos que o primeiro visava obter. Com a conversão, então, não se conserva a figura do ato original, mas compõe-se outro, válido, com as peças válidas que o primeiro contém (NETTO DE ARAÚJO, 1999, p. 145).

$\mathrm{Na}$ hipótese de conversão de atos administrativos de competência vinculada, a modificação poderá ser realizada pelo Poder Judiciário e os efeitos serão sempre retroativos (ex tunc). Deve-se atentar, contudo, que à luz do caso concreto, conforme as circunstâncias fáticas e da ponderação dos princípios incidentes, apesar de não 
ser reconhecida por parte da doutrina, o Direito exija a conversão para sanar o vício existente (MARTINS, 2019).

\subsection{CONVALIDAÇÃO}

A convalidação consiste no aproveitamento do ato administrativo inválido, mediante o saneamento total do vício[15]. O ato administrativo inválido é integralmente aproveitado, ou seja, permanece no sistema da mesma forma como foi editado (MARTINS, 2019).

Nas lições de Sundfeld (1990), a convalidação se dá mediante um novo ato que tem dupla finalidade, a de reconhecer a invalidade de um ato passado e herdar os seus efeitos. O autor ainda esclarece que a convalidação é constituída por um novo ato administrativo que difere da repetição do ato inválido com a correção do vício. Devese analisar se é possível repetir o ato sem o vício e se à época já era possível tal prática, assim como deve ser avaliada a possibilidade de este novo ato retroagir (SUNDFELD, 1990).

São suscetíveis à convalidação os atos viciados quanto à competência, formalidade e procedimento, este último quando a falta de ato ou atos da Administração não prejudicar a finalidade e quando ausente o ato do particular que, praticado a posteriori tenha expressa intenção de retroagir (ZANCANER, 2008).

Sobre a convalidação dos atos administrativos por vício de procedimento, entendido como ausência ou defeito de ato praticado no procedimento administrativo, suscetível de ser sanado, Weida Zancaner explica que, quanto à ausência de ato do particular exigido, é possível a convalidação desde que o administrado aquiesça em praticar o ato saneador com o propósito de retroagir, assim como há restrição na convalidação se houver alteração da finalidade:

Assim, todas as vezes que a Administração Pública puder convalidar um ato, dos que se encadeiam no procedimento, deverá fazê-lo. Fica-lhe, todavia, vedado convalidar qualquer ato, no decorrer ou após o procedimento, se a convalidação gerar desvirtuamento da finalidade em razão da qual o procedimento foi instaurado (ZANCANER, 2008, p. 89). 
O ato administrativo que contém vício de conteúdo ou de finalidade não pode ser convalidado, pois se somente é admissível a convalidação de atos administrativos que poderiam ter sido expedidos à época sem o vício, é possível afirmar que o conteúdo que viola a lei não pode ser novamente praticado com a mesma violação ao ordenamento, da mesma forma, que no vício de finalidade é impossível repetir a prática do ato se a finalidade é igualmente inadmitida pelo Direito (SUNDFELD, 1990).

A convalidação realizada pelo mesmo agente que editou o ato inválido é denominada ratificação e, quando efetuada por outro agente, é denominada confirmação. Além disso, a convalidação pode ser vinculada ou discricionária. Na hipótese de convalidação vinculada, poderá ser submetida ao Judiciário para a respectiva convalidação, enquanto na discricionária só poderá ser realizada pela Administração Pública (MARTINS, 2019).

Visando a restauração da legalidade, na hipótese de convalidação, preenchidos os requisitos legais, deverá haver fundamentação da Administração Pública com exposição expressa dos motivos pela autoridade competente que justificam a necessidade de convalidação e que essa é a modalidade de modificação do ato administrativo que melhor atende o interesse público.

Assim, diante de um vício existente, é possível que as duas hipóteses, seja ela a invalidação ou a convalidação, sejam igualmente admitidas pelo Direito, sendo necessário à Administração ponderar os princípios incidentes à luz do caso concreto. Se a solução jurídica, na escolha do meio de correção, diante de todos os princípios incidentes, apontar que há uma única solução, então, esta será vinculada, podendo ser submetida a controle jurisdicional. De outro lado, se ao ponderar os princípios incidentes, houver duas soluções igualmente possíveis, admitidas em Direito, então a convalidação poderá ser discricionária (MARTINS, 2019).

Posição contrária é apresentada por Zancaner (2008), que entende não haver liberdade discricionária que faculte à Administração o poder de decidir entre invalidar ou convalidar, exceto quando se tratar de ato de competência discricionária praticado por autoridade incompetente. Conforme consta em sua obra, 
Como decorrência do exposto, inexiste no denominado poder de invalidar liberdade discricionária que dê à Administração o genérico poder de decidir, por um critério subjetivo, se entende conveniente ou não invalidar, se vai ou não convalidar, se pode optar por convalidar ou invalidar, pois inexiste, em nosso sistema jurídico-positivo norma que sirva de fundamento jurídico para tanto; isto é, inexiste norma jurídica que confira à Administração Pública genérica liberdade para decidir se pretende invalidar ou não, ou convalidar ou não, seus atos maculados com vícios (ZANCANER, 2008, p. 64).

Quanto ao objeto, fundamento e motivo da convalidação, Martins (2019), esclarece que:

O objeto da convalidação é o ato administrativo inválido, portador de um vício que admita a repetição do ato com idêntico conteúdo e sem o vício. O fundamento da convalidação são os mesmos da invalidação, acrescidos das razões que justifiquem a manutenção do ato no sistema: segurança jurídica, estabilização das relações jurídicas, confiança legítima, boa-fé do administrado. O motivo da convalidação é a contrariedade do ato ao Direito e a necessidade de correção do vício (MARTINS, 2019, p. 414).

Com relação à possibilidade de convalidação do ato administrativo se houve impugnação pelo administrado, cabe à Administração Pública ponderar a manifestação do administrado, na medida em que, prima facie, a impugnação colabora em benefício da pretensão do impugnado. Do mesmo modo, quanto aos requisitos procedimentais e formalísticos, estes deverão seguir as mesmas regras do ato corrigido, observado que a convalidação, em regra, deverá ser motivada e, na hipótese de o processo administrativo em que 0 ato inválido foi editado já ter terminado, deverá ser instaurado um novo processo administrativo convalidante. Além disso, ao sanar o vício desde sua edição, os efeitos da convalidação serão retroativos (MARTINS, 2019) [16].

Sobre a possibilidade de retroação dos efeitos do ato convalidador, com o novo ato, "modifica-se a qualificação de acontecimentos verificados no passado e de todos os efeitos deles decorrentes, de modo a se produzir, no presente, o quadro que existiria se, desde o passado, tais eventos tivessem sido qualificados como o são agora" (SUNDFELD, 1990). 


\section{ESCOLHA DO MEIO DE CORREÇÃO}

Existem duas posições doutrinárias a respeito da escolha do meio de correção, sendo a primeira a teoria subjetiva que indica não ser possível especificar de forma rígida quais são os vícios que geram invalidação e os vícios sujeitos à convalidação e, a segunda, a teoria objetiva que sustenta ser possível a indicação das hipóteses em que o ato deverá ser invalidado e as hipóteses em que o ato deverá ser convalidado. Concorda-se com a posição teórica subjetiva e no sentido de que se deve realizar uma ponderação entre os princípios incidentes, para que seja possível sopesar "o tempo decorrido, os efeitos gerados, da boa ou da má-fé do administrado e do agente público, dos valores afetados com a retirada do ato" no momento de exame da invalidade que, diante das circunstâncias fáticas e jurídicas, haverá a indicação do meio de correção mais adequado que melhor atenda ao interesse público (MARTINS, 2019, p. 415) [17].

O agente público, em determinadas situações, poderá ter competência discricionária para escolha entre a convalidação e a invalidação, pois ambas podem ser válidas. Entretanto, é importante que haja a correta ponderação entre todos os princípios incidentes, pois é possível que a competência seja discricionária no plano abstrato, mas à luz do caso concreto, a invalidação seja inútil ou até mesmo danosa, hipótese em que a convalidação será obrigatória (SUNDFELD, 1990).

Não se pretende afastar a possibilidade de a Administração Pública exercer o dever de buscar a legalidade do ato pela invalidação, contudo, entende-se possível para as licenças de construção, sendo ato administrativo vinculado, se concedidas com vício quanto à competência, formalidade e procedimento, entende-se possível a modificação para torná-las regular.

Sobre o tema, Márcia Walquiria Batista dos Santos (2001), ao analisar a licença de construção, apresenta posicionamento favorável à anulação do ato administrativo ilegal, sem precisar quais seriam as hipóteses de vícios, manifestando que somente não deverão ser anulados os atos quando o prejuízo da extinção do ato for maior. Nas suas palavras: 
Para nós, a Administração tem, em regra, o dever de anular atos ilegais, sob pena de cair por terra, o princípio da legalidade. No entanto, poderá deixar de fazê-lo em circunstâncias determinadas, quando o prejuízo resultante da anulação puder ser maior do que o decorrente da manutenção do ato ilegal; neste caso, é o interesse público que norteará a decisão (BATISTA DOS SANTOS, 2001, p. 132).

Deve-se ressaltar que há princípios que justificam a manutenção do ato administrativo, assim como existem princípios que justificam a retirada do ato administrativo do sistema. No âmbito do direito administrativo, há ainda um "princípio de conservação de normas editadas, pelo qual o sistema jurídico prefere sempre a máxima conservação do ato praticado". Assim, com fundamento nos princípios da segurança jurídica, boa-fé, da economicidade e da conservação das normas editadas, é possível afirmar que entre a invalidação e o saneamento, o direito aponta a favor do saneamento, assim como entre a convalidação, conversão ou redução, o direito aponta a favor da convalidação (MARTINS, 2019, p. 417).

Além dos princípios incidentes que justificam a modificação do ato administrativo para torná-lo regular, importante considerar, ainda, os efeitos reflexos[18] gerados pela licença de construção inválida expedida pela Administração Pública, especialmente se a construção já foi concluída e se, por exemplo, centenas de consumidores estão envolvidos nesta relação jurídica de efeito reflexo.

Assim, diante de vícios relacionados à competência, formalidade e procedimento, entende-se que a Administração Pública ao realizar a ponderação à luz do caso concreto, deverá levar em consideração o tempo decorrido, os efeitos típicos e reflexos gerados, assim como ponderar os princípios da segurança jurídica, boa-fé, da economicidade e da conservação das normas editadas, sem prejuízo do princípio da legalidade, a fim de identificar o meio de correção mais adequado que melhor atenda ao interesse público.

\section{CONCLUSÃO}

O direito urbanístico considerado como conjunto de princípios e normas que visam regular a ocupação do espaço urbano em prol do bem estar da coletividade, 
submetidos ao regime de direito público, impõe para o planejamento urbano limitações para o exercício do direito de propriedade.

Conforme tratado ao longo deste trabalho, as regras de uso e ocupação do solo e as normas edilícias definem os critérios que devem ser cumpridos para o atendimento da função social da propriedade urbana, sendo a licença de construção um instrumento de controle urbanístico, que tem a finalidade de a Administração Pública atestar a observância das normas pelos seus destinatários.

A licença de construção constitui ato administrativo que visa atestar a conformidade com as normas de direito público que disciplinam o direito de construir, observadas as restrições urbanísticas e ao direito de vizinhança. Tratando-se de ato administrativo de competência vinculada, se atendidos os requisitos legais, a Administração Pública declara o direito de o administrado construir, por meio da expedição da licença.

Conforme abordado no presente estudo, é possível que a Administração Pública conceda a licença de construção com vícios sujeitos à invalidação, sejam nos atos praticados no procedimento administrativo até se alcançar o Alvará de Construção, que representa 0 ato conclusivo da licença de construção.

Tratando-se de vícios relacionados à competência, formalidade e procedimento, o Direito admite a correção do vício, que poderá se realizar mediante as possiblidades existentes para modificação do ato inválido, seja por meio da estabilização, redução ou reforma, conversão ou convalidação, conforme a opção que melhor atenda ao interesse público diante da ponderação a ser realizada entre as circunstâncias fáticas e os princípios incidentes.

Diante do que foi apresentado, a ponderação para a correta decisão, observando-se que o Direito aponta para entre sanar o vício e modificá-lo para torná-lo regular, deve ser realizada com fundamento na teoria subjetiva, sopesando-se o tempo que decorreu entre a prática do ato administrativo e a análise para possível modificação do ato, assim como os efeitos não só típicos, mas os efeitos reflexos gerados a terceiros, os valores afetados a fim de que haja a correta indicação do meio adequado 
que melhor atenda ao interesse público, especialmente em atenção aos princípios da segurança jurídica, estabilização das relações jurídicas, confiança legítima, boa-fé do administrado e da economicidade, além do princípio da conservação das normas jurídicas.

\section{REFERÊNCIAS}

BANDEIRA DE MELLO, C. A. Curso de Direito Administrativo. 34ª ed., São Paulo: Malheiros Editores, 2019.

BATISTA DOS SANTOS, M. W. Licença Urbanística. São Paulo: Malheiros Editores, 2001.

BIGOLIN, G. Segurança Jurídica. A estabilização do Ato Administrativo. Porto Alegre: Livraria do Advogado Editora, 2007.

CÂMARA, J. A. A preservação dos efeitos dos atos administrativos viciados. Revista Diálogo Jurídico, Salvador, CAJ - Centro de Atualização Jurídica, № 14, junho/agosto, 2002. Disponível na internet: <http://www.direitopublico.com.br/>. Acesso em 24.11.2019.

DALLARI, A. A. Licenças Urbanísticas e Desvio de Poder. In: Direito Administrativo e Liberdade. Estudos em Homenagem a Lúcia Valle Figueiredo. Coordenadores: Celso Antônio Bandeira de Mello, Sérgio Ferraz, Silvio Luís Ferreira da Rocha e Amauri Fedes Saad. São Paulo: Malheiros Editores, 2014.

FIGUEIREDO, L. V. Disciplina Urbanística da Propriedade. 2ª ed., São Paulo: Revista dos Tribunais, 2005.

GORDILLO, A. El Acto Administrativo. In: Tratado de Derecho Administrativo. Tomo III, Fundación de Derecho Administrativo. Buenos Aires, 2003.

LIRA, R. P. Elementos de Direito Urbanístico. Rio de Janeiro: Renovar, 1997. 
MALUF, P. T. Licença de construção e plano urbanístico no direito português. In: Direito Urbanístico e Ambiental. Coordenadores: Adilson Abreu Dallari e Daniela Campos Libório Di Sarno. Belo Horizonte: Editora Fórum, 2007.

MARTINS, R.M. e BACELLAR FILHO, R. F. Tratado de direito administrativo: ato administrativo e procedimento administrativo. Coord. Maria Sylvia Zanella Di Pietro. $2^{\mathrm{a}}$ ed., vol. 5, 2019.

MARTINS, R. M. Efeitos dos Vícios do Ato Administrativo. São Paulo: Malheiros Editores, 2008.

MARTINS, R. M. Estudos de Direito Administrativo Neoconstitucional. São Paulo: Malheiros Editores, 2015.

NETTO DE ARAÚJO, E., Convalidação do Ato Administrativo. São Paulo: Editora LTR, 1999.

REALE, M. Revogação e Anulamento do Ato Administrativo. São Paulo: editora Forense, 1968.

SAMPAIO SILVA, C. Limites à invalidação dos atos administrativos. São Paulo: editora Max Limonad, 2001.

SILVA, J. A. Direito Urbanístico Brasileiro. $7^{\text {a }}$ ed. São Paulo: Malheiros Editores, 2012.

SIMÕES, M. M. T. O processo administrativo e a invalidação de atos viciados. São Paulo: Malheiros Editores, 2004.

SUNDFELD, C. A. Ato Administrativo Inválido. São Paulo: Editora Revista dos Tribunais, 1990.

SUNDFELD, C. A. et. al. O Estatuto da Cidade e suas Diretrizes Gerais. In: Estatuto da Cidade. São Paulo: Malheiros Editores, 2002. 
SAULE JUNIOR, N. S. et. al. Estatuto da Cidade e o Plano Diretor-Possibilidades de uma Nova Ordem Legal Urbana Justa e Democrática. Porto Alegre: Sérgio Antônio Fabris, 2002.

SAULE JUNIOR, N. S. Novas Perspectivas do Direito Urbanístico Brasileiro. Ordenamento Constitucional da Política Urbana. Aplicação e Eficácia do Plano Diretor. Porto Alegre: Sérgio Antônio Fabris Editor, 1997.

SAULE JUNIOR, N. S. et al. Os Caminhos para o Desenvolvimento da Função Socioambiental da Propriedade Pública no Brasil. Rio de Janeiro: Forense, 2014.

ZANCANER, W. Da Convalidação e da Invalidação dos Atos Administrativos. 2ª ed., São Paulo: Malheiros Editores, 2008.

\section{APÊNDICE - REFERÊNCIAS DE NOTA DE RODAPÉ}

3. Ricardo Marcondes Martins explica que "o legislador federal, ao editar normas gerais de direito urbanístico, além de se ater a comandos com destinatário e ações universais e observar o resultado de uma ponderação entre os princípios da segurança jurídica e da igualdade, deve, necessariamente, atentar para as competências privativas em matéria de direito urbanístico atribuídas às demais entidades federativas: os Estados possuem competência privativa para instituição de regiões metropolitanas e aglomerações urbanas e microrregiões, nos termos do art. 25, §3; e os Municípios, competência privativa para legislar sobre assuntos de predominante interesse local, nos termos do art. 30, I, - e, consequentemente, para editar o Plano Direto, nos termos do art. 182, $\$ 1^{\circ}$, da CF” (MARTINS, 2015, pp. 121 122).

4. José Afonso da Silva apresenta a distinção entre atos urbanísticos procedimentais e atos urbanísticos isolados. Atos urbanísticos procedimentais são os que se ordenam num procedimento urbanístico, como atos integrantes, por exemplo, de um plano de reurbanização. São atos urbanísticos isolados aqueles que não se inserem num procedimento, como um decreto que, de acordo com a lei, fixa as zonas de uso ou 
estabelece os limites da zona urbana; atos de aprovação de um plano de arruamento ou de loteamento; um certificado de uso do solo; um alvará de licença para construir; o "habite-se" - sendo que os dois últimos não são apenas urbanísticos, porque também se inserem no campo do direito de construir (SILVA, 2015, p. 46-47).

5. Ricardo Marcondes Martins esclarece, quanto à licença de construção, que, quem é proprietário, tem direito de construir, respeitadas às regras vigentes, ou seja, a Administração reconhece um direito prévio e apenas atesta esse direito. Acrescenta, ainda, que é um ato declaratório e sendo assim, pode ser impugnado em juízo na hipótese de indeferimento, para obter judicialmente o licenciamento pretendido, considerando se tratar de ato administrativo declaratório (MARTINS, 2019, p. 152).

6. Celso Antônio Bandeira de Mello classifica o ato administrativo válido aquele expedido "em absoluta conformidade com as exigências do sistema normativo. Vale dizer, quando se encontra adequado aos requisitos estabelecidos pela ordem jurídica. Validade, por isto, é a adequação do ato às exigências normativas" (BANDEIRA DE MELLO, 2019, p. 395). Contudo, Ricardo Marcondes Martins esclarece que nem todo ato desconforme com o Direito é inválido, pois há hipóteses em que há irregularidade, mas o sistema jurídico não exige a sua correção, ou seja, não exige que seja invalidado e tampouco convalidado (MARTINS, 2019, p. 159-163).

7. Celso Antônio Bandeira de Mello aponta que existem três posições diferentes quanto aos atos administrativos inválidos no direito brasileiro. O primeiro deles, é apresentado no sentido de que o vício acarreta sempre a nulidade do ato, sendo esta a posição de Hely Lopes Meirelles. O segundo, defendido por Oswaldo Aranha Bandeira de Mello, segue afirmação de que atos nulos não são convalidáveis, ao passo que os anuláveis o são. Esta mesma corrente defende que os atos nulos podem ser fulminados quando provocados pelo Ministério Público ou de ofício pelo juiz, enquanto os anuláveis dependem de arguição pelo interessado, assim como atos nulos só prescrevem longi temporis, enquanto os anuláveis prescrevem brevi temporis. A terceira corrente, apresentada por Seabra Fagundes, defende uma divisão tricotômica em atos nulos, anuláveis e irregulares, ressalvando que as duas primeiras 
espécies não correspondem com a do Código Civil, quanto aos tipos de vícios ou efeitos (BANDEIRA DE MELLO, 2019, p. 479).

8. Para Weida Zancaner, ressalvados os atos de competência discricionária praticados por autoridade incompetente, ou há dever de invalidar, ou há dever de convalidar, ou nenhuma das providências pode ser adotada (ZANCANER, 2008, p. 64). Sobre a estabilização, a autora trata como "barreiras ao dever de invalidar". Já para Jacintho Arruda Câmara, a preservação dos efeitos do ato viciado pode se dar de duas formas, por meio da convalidação dos atos administrativos ou pela estabilização dos efeitos do ato administrativos viciados (CÂMARA, 2002, p. 7). Clarissa Sampaio Silva também adota a corrente que admite invalidação ou convalidação dos atos administrativos, apresentando que em determinadas situações o ato passível de invalidação pode ser sanado, eliminando-se o vício (SAMPAIO SILVA, 2001, p. 127). Posição divergente, parcialmente adotada neste estudo, é apresentada por Agustín Gordillo que apresenta a seguinte posição: "vimos que si el vicio no es muy grave es posible mantener la vigencia del acto, suprimiendo o corrigiendo el vicio que lo afecta: esto es lo que según los casos y los autores se llama saneamiento, perfeccionamiento, confirmación, convalidación, ratificacion, etc". (GORDILLO, 2003, p. XII-8).

9. Apoiando-se na classificação apresentada por Ricardo Marcondes Martins, os atos de efeitos favoráveis ao administrado é mais amplo do que a classe dos efeitos ampliativos, pois "nem o ato que indefere a aplicação de uma sanção nem o ato que substitui uma sanção mais gravosa por uma menos gravosa ampliam a esfera d administrado (MARTINS, 2019, p. 150).

10. Sobre o tema, Giovani Bigolin defende que "a solução do impasse passa, portanto, por uma correta ponderação entre todos os interesses atingidos pela nulidade em foco". Acrescenta, ainda, que sempre que as normas não esgotarem os juízos possíveis de ponderação entre os interesses públicos e privados envolvidos, caberá à Administração realizar a ponderação de todos os interesses e atores envolvidos em prol da máxima realização do interesse público (BIGOLIN, 2007, p. 111). 
11. Clarissa Sampaio Silva ainda acrescenta que "confronta-se diretamente com o princípio da segurança jurídica a possibilidade de a Administração a qualquer tempo invalidar seus atos, mesmo que transcorrido longo lapso temporal e, principalmente, acaso estes tenham gerado situações ampliativas de direito (devidamente consolidadas) para particulares que estejam de boa-fé" (SAMPAIO SILVA, 2001, p. 92).

12. Clarissa Sampaio Silva esclarece que no âmbito do Direito Administrativo deve-se conferir ainda maior proteção à boa-fé dos administrados, em razão das particularidades e prerrogativas da Administração Pública, tais como a supremacia do interesse público, a auto executoriedade, a possibilidade de revogação e invalidação dos seus próprios atos, a contratação com cláusulas exorbitantes, exercício do poder de polícia, imposições de restrições administrativas á propriedade, dentre outras (SAMPAIO SILVA, 2001, p. 117).

13. Oswaldo Aranha Bandeira de Mello apresentou em sua obra como "redução" (Princípios Gerais de Direito Administrativo, 3를 ed., vol I, p. 663), enquanto Edmir Netto de Araújo denomina "reforma" (Convalidação do Ato Administrativo, São Paulo, 1999, p. 147).

14. A esse respeito, Ricardo Marcondes Martins concorda com o posicionamento de Carlos Ari Sundfeld no sentido de que não há salvamento do ato inválido, mas sim de seus efeitos, pois o ato corretor retira o ato viciado e ao mesmo tempo "herda" os efeitos produzidos por ele (Ato Administrativo Inválido, São Paulo. Ed. RT, 1990, pp.50-53).

15. Edmir Netto de Araújo prefere a designação de conservação dos atos administrativos para o gênero, sob o fundamento do poder-dever da atividade da Administração, alinhada com o princípio da conservação dos valores jurídicos ao lado do princípio da autotutela. Para este autor, as modalidades de conservação são: ratificação, conversão, reforma e confirmação (NETTO DE ARAÚJO, 1999, p. 123). 
16. Ricardo Marcondes Martins indica as três correntes doutrinárias sobre o tema, sendo a primeira no sentido de que a impugnação constitui barreira à convalidação (BANDEIRA DE MELLO, Celso Antônio. Curso de direito administrativo, p. 486), a segunda que defende ser irrelevante a impugnação, uma vez que o interesse público é que exige a convalidação (FERRAZ, Sérgio. Extinção dos atos administrativos: algumas reflexões. Revista de Direito Administrativo, Rio de Janeiro, n. 231, p. 47-66, p. 63-64) e a terceira defendida pelo autor, no sentido de que a impugnação gera, tão somente, uma razão prima facie em prol da pretensão do impugnante (MARTINS, 2019, p. 409-410). Sobre o tema, Weida Zancaner também se posiciona no sentido de que a mera impugnação do administrado constitui barreira à convalidação (ZANCANER, 2008, p. 72).

17. Ricardo Marcondes Martins apresenta em sua obra as duas teorias, a objetiva e a subjetiva. Aponta que dentre os autores que defendem a teoria subjetiva encontra-se Miguel Seabra Fagundes, sendo que para teoria objetiva a defesa é apresentada por Weida Zancaner. A posição da teoria subjetiva fundamenta que o direito administrativo é composto por institutos ainda não mal cristalizados e que não comporta uma capitulação precisa, enquanto para teoria objetiva, o fundamento apresentado é no sentido de que o interesse público não pode ser utilizado como critério para escolha do meio de correção porque tornaria o administrador "o senhor do regime aplicável do ato" (MARTINS, 2019, P. 414).

18. Ricardo Marcondes Martins explica que os efeitos típicos são aqueles decorrentes da própria tipologia do ato, enquanto "os efeitos reflexos implicam a instituição de outra relação jurídica, estranha à relação típica". Apresenta, como exemplo, a desapropriação em que o efeito típico será entre a Administração e o proprietário, no dever de pagar a justa indenização e de outro lado a aquisição da propriedade. $\mathrm{Na}$ hipótese de haver um locatário no imóvel, o efeito reflexo neste caso, implicará na extinção desse contrato de locação celebrado com terceiro (MARTINS, 2019, p. 260261).

Enviado: Dezembro, 2019. 
Aprovado: Dezembro, 2019. 